\title{
MIGRATION OF THE CURIMBATÁ Prochilodus lineatus (VALENCIENNES, 1836) (PISCES, PROCHILODONTIDAE) AT THE WATERFALL “CACHOEIRA DE EMAS” OF THE MOGI-GUAÇU RIVER - SÃO PAULO, BRAZIL*
}

\author{
CAPELETI, A. R. and PETRERE JR., M. \\ Departamento de Ecologia, UNESP, C. P. 199, CEP 13506-900, Rio Claro, SP, Brazil \\ Correspondence to: Miguel Petrere Jr., Departamento de Ecologia, UNESP, C. P. 199, \\ CEP 13506-900, Rio Claro, SP, Brazil, e-mail: mpetrere@ @rc.unesp.br \\ Received August 3, 2004 - Accepted November 29, 2004 - Distributed May 31, 2006
}

(With 3 figures)

\begin{abstract}
In this paper, we counted the ascending curimbatás at the fish ladder at the Cachoeira de Emas from October, 1992 to September, 1993 in one whole day ( $24 \mathrm{~h}$ period) per month at different observation points in the dam for 5 min every hour. Most of the fish (80\%) were counted not in the fish ladder itself, but in two adjacent spillways at its left, perhaps due to the comparatively increased flow as they are narrower than the ladder. The bulk of the migration occurred in September/October. We inspected the degree of injury of the fish in order to examine the hypothesis that larger fish are less injured, however no conclusion was reached. The degree of injury varied between different points and in different months of the year.
\end{abstract}

Keywords: curimbatá, Prochilodus lineatus, freshwater fish migration, cachoeira de Emas, fish ladder, Brazil.

\section{RESUMO}

\section{Migração do curimbatá Prochilodus lineatus (Pisces, Prochilodontidae) na cachoeira de Emas, no rio Mogi-Guaçu - SP, Brasil}

Neste artigo, contamos os curimbatás na escada de peixes da Cachoeira de Emas, de Outubro/92 a Setembro/93, num dia durante $24 \mathrm{~h}$ por mês, em diferentes pontos de observação da barragem, durante 5 min a cada hora. A maioria dos peixes $(80 \%)$ foi observada e contada não na escada de peixes, mas em dois vertedouros adjacentes à sua esquerda, talvez devido ao maior fluxo de água, pois são mais estreitos que a escada. O pico da migração ocorreu em Setembro/Outubro. Inspecionamos o grau de injúria dos peixes a fim de examinar a hipótese de que peixes maiores estariam menos feridos, porém não chegamos a uma conclusão clara. O grau de injúria variou entre diferentes pontos e entre diferentes meses do ano.

Palavras-chave: curimbatá, Prochilodus lineatus, migração de peixes de água doce, cachoeira de Emas, escada de peixes, Brasil.

\section{INTRODUCTION}

Many fish species undertake regular migrations at different time scales ranging from daily to annual, and distances that range from a few meters (mostly in lateral habitat migration) to thousands of kilometers. The main objective relates either to feeding or breeding albeit in some cases the reason is unknown.

In short the word "migration" can also be defined as the "movements resulting from the change between two or more separate habitats.... occurring with a regular periodicity......and involving a large part of the population" (Northcote, 1984).

\footnotetext{
* This paper is dedicated to the memory of Prof. Manuel Pereira de Godoy for his outstanding achievements when studying the Prochilodus lineatus migrations at Cachoeira de Emas.
} 
Migratory movements, with many exceptions, follow classic and seasonal models: upstream (reproductive zone), downstream (feeding zone) and lateral movements on the floodplain during the rainy season. For many riverine fish species, the beginning of migration coincides with the coming of the floods followed by changes in the current speed, turbidness, water level, etc. However, migrations are not dependent on a single stimulus, but are related to changes in the water temperature, concentration of $\mathrm{CO}_{2}$ and moon rhythms, among others (FAP 17, 1992). Variations in the migration pattern can occur, mainly due to environmental differences rather than taxonomic ones. Fish species that undertake extensive migrations for reproductive and trophic ends exist in almost all the river basins of Latin America (Agostinho et al., 2003; Petrere, 1985; Quirós, 1988). In the Paraná river basin, the genus Prochilodus is known as it undertakes upstream migrations, preceded by the annual floods and followed by oviposition. The feeding areas are usually lentic habitats (Godoy, 1954; 1957; 1959; 1962; 1967; 1972; 1987; Bayley, 1973; Bonetto \& Pignalberi, 1964; Bonetto et al., 1981).

In total, 1,200 to $1,400 \mathrm{~km}$ are covered upstream and downstream in a complete migratory cycle. This distance reveals that the metabolism of these fish is possibly linked to the biological necessity of swimming which is one of the factors that conditions gonad maturation and triggers the reproductive event. The upstream migration to the so-called "reproductive homes" begins in AugustSeptember coinciding with the first rains and a rise in temperature. After oviposition, fish undertake trophic downstream migrations to their "feeding homes" (Godoy, 1954; 1957; 1962; 1972). The migration periodicity was proved by recapturing a curimbatá during three consecutive years on the same day and at the same place (Godoy, 1967). The upstream migration of the shoals occurs during the day and also at night, in heterogeneous age groups, that include fish which are not mature yet (Godoy, 1959).

Bonetto \& Pignalberi (1964), discuss that a single shoal assembles fish in various physiological stages relative to the mechanisms that determine their migratory behavior. It is difficult to assert until which point sexual stimulus is responsible for the migrations, since the complex relationships that exist between the environmental variables and the physiological processes seem to be of fundamental importance. Therefore, the lifecycle of some Characiformes and Siluriformes includes the necessity to migrate where in many cases the dams are inaccessible obstacles (Godinho et al., 1991). Nevertheless, this negative aspect can diminish by making a passage for the fish. Among the fish ladders constructed in the South and Southeast regions of Brazil, only the fish ladder at the Cachoeira de Emas of the Mogi-Guaçu river and the ladder at the Salto de Morais of the Tijuco river present data about their efficiency. Godinho et al. (1991) show that the fish ladder at the Salto de Morais is selective for some species of fish where only $2 \%$ of the individuals are able to reach the higher sections of the ladder. The ladder at Cachoeira de Emas is comparatively more efficient as there is a passage for a great number of species as well as individuals (Godoy, 1987).

Recently Agostinho et al. (2002) reviewed the efficiency of fish ladders for Neotropical ichthyofauna and concluded that in most situations they are an inadequate preservation instrument mainly in rivers with a cascade of large reservoirs.

The biomass of fish communities in the large rivers in Latin America is dominated by Characiformes and Siluriformes (Lowe-McConnell, 1999). Among the Characiformes, the genus Prochilodus and Semaprochilodus, constitute the most important amount of captures; more than 60-70\% in some systems. Quirós (1988), Payne (1986) and Bayley (1973) describe the sabalo (Prochilodus lineatus) as being the largest part of the biomass in the Pilcomayo river. In 1987, the most captured fish at the Cachoeira de Emas of the Mogi-Gauçu river was the curimbatá, representing $90 \%$ of the total captures (Petrere, 1989). Sverlij et al. (1993) present an useful synopsis of Prochilodus lineatus.

According to Godoy (1987), various factors contribute to the decrease in fishing at the MogiGuaçu: general pollution, reduction of the "feeding home" at the Grande river due to the presence of a cascade of reservoirs, devastation of the marginal forests, destruction of the marginal lagoons and overfishing.

The main aim of this paper was to observe the migratory behavior of the curimbatá during the day and night periods and to assess how the fish ladder 
is influencing it. Another objective was to evaluate the apparent condition of the fish examining possible ontogenetic (fish length), spatial (different jumping points) and temporal (different months) variations during the reproductive migration.

\section{MATERIAL AND METHODS}

\section{Study area}

The fish of the Mogi-Guaçu river (Fig. 1) undertake reproductive migrations upstream and trophic migrations downstream. The ecosystem encompassed by the species in the upper Paraná basin is formed by three rivers: Grande (intermediate part), Pardo (lower part) and Mogi-Guaçu (Fig. 1); it is situated between the longitudes of $47^{\circ} 30^{\prime} \mathrm{O}$ " $\mathrm{W}$ and $49^{\circ} 15^{\prime} 0^{\prime \prime} \mathrm{W}$ and the latitudes of $20^{\circ} 3^{\prime} 0^{\prime \prime} \mathrm{S}$ and $22^{\circ} 30^{\prime} 0$ " S. The Mogi-Guaçu river is $473 \mathrm{~km}$ long and has an average width of $60 \mathrm{~m}$. Its spring is situated at an altitude of $1,600 \mathrm{~m}$ and its mouth at $470 \mathrm{~m}$. It has a water basin of $17,750 \mathrm{~km}^{2}, 84 \%$ of which is situated in the State of São Paulo.

\section{Daily migration rhythm}

In order to estimate the daily migration rhythm of the curimbatá, we carried out a visual count of the individuals of the species that try to

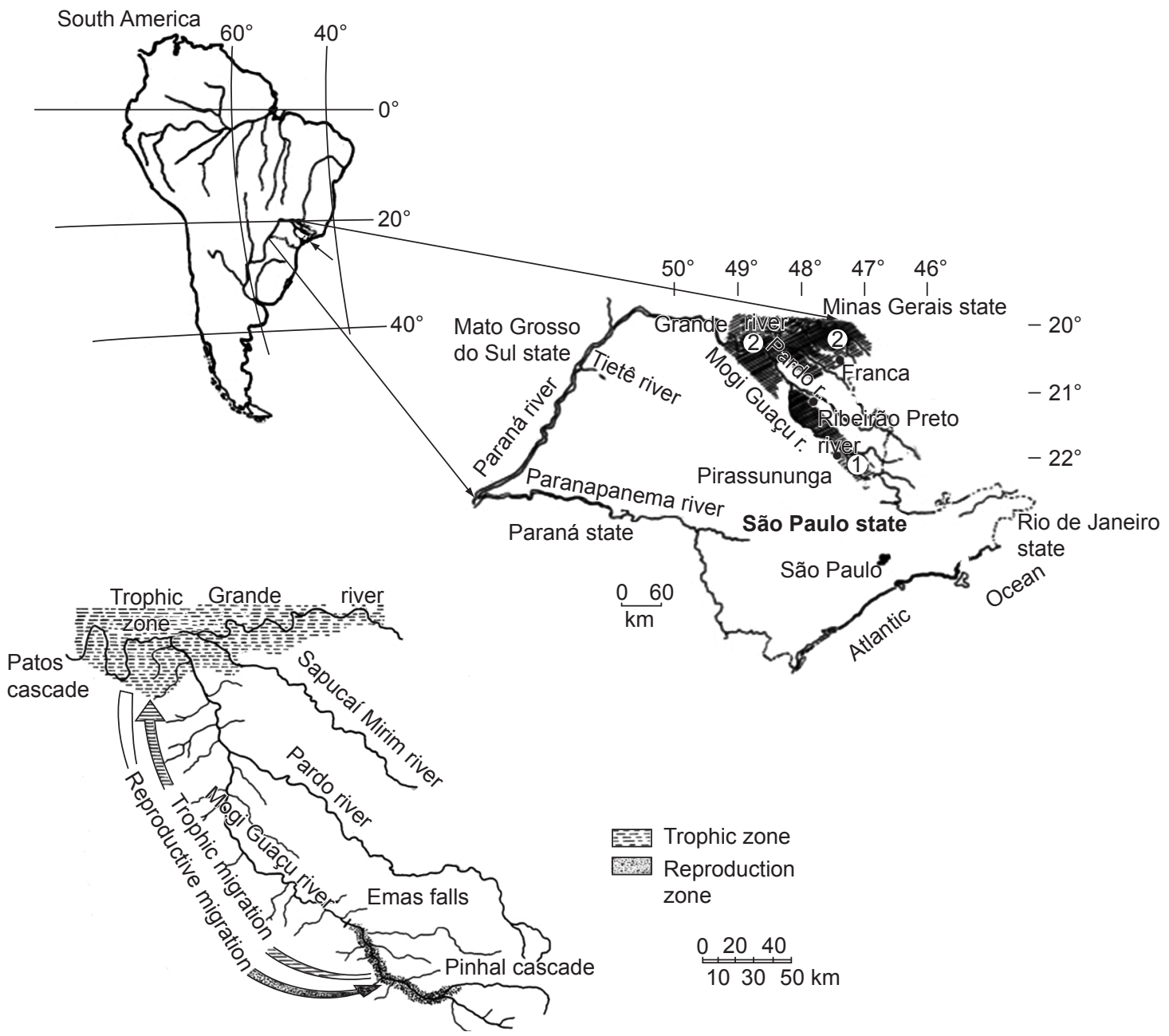

Fig. 1 - Map of the Mogi Guaçu river basin. 
swim upstream the Mogi-Guaçu river (reproductive migration, Godoy, 1954, 1959), at the CESP dam of Cachoeira de Emas. The observation area is located at the Mogi-Guaçu river, Pirassununga District at the Cachoeira de Emas dam (Fig. 2).

Four different counting points were stipulated (Fig. 2):

- Point 1: Spillway to the right of the fish ladder;

- Point 2: Spillway to the right of the fish ladder, adjacent to Point 1 ;

- Point 3: Fish ladder; and

- Point 4: Spillway to the left of the fish ladder.

These points were chosen with the purpose of observing the migration rhythms at places with distinct characteristics, i.e. points 1 and 2 are similar.

In each month, one day was chosen and counting the fish was undertaken for $24 \mathrm{~h}$ of uninterrupted observation every hour for $5 \mathrm{~min}$ at each point (numbered above). At each hour, the air and water temperatures were measured. Since the method is visual, one must consider the possibility of counting other species of fish, and the same individual more than once, mainly at night. However, since the biomass of curimbatás is very abundant in this area, this aspect becomes irrelevant.

\section{Length frequency}

The data for the length frequencies were collected at the Mogi-Gauçu river close to the CESP dam of Cachoeira de Emas.
Another four collection points (Fig. 2) were determined:

- Point 5: Left hand side; downstream from the dam;

- Point 6: right hand side; downstream from the dam;

- Point 7: upstream from the dam; and

- Point 8: In front of the fish ladder, before the first step; downstream from the dam.

The sampling took place from September, 1992 to March, 1993, including the period of the main months of upstream migration (Godoy, 1987). We captured curimbatás with nets of different mesh sizes: $9 \mathrm{~cm}, 10 \mathrm{~cm}, 12 \mathrm{~cm}$ and others with double mesh nets of $9 \mathrm{~cm} / 14 \mathrm{~cm}, 9.5 \mathrm{~cm} / 14 \mathrm{~cm}$, $9 \mathrm{~cm} / 15 \mathrm{~cm}$ and $7 \mathrm{~cm} / 21 \mathrm{~cm}$ in the hope of minimizing the effect of selectivity. The meshes were repeated at the different collection points in order to be able to compare the fish lengths. We measured the total, fork and standard lengths with an ictiometer. We used the fork length for the analysis since many individuals appeared not having their caudal fins intact.

\section{Comparison of the length of the individuals per collection point}

The measurements for the fish lengths were separated by collection points, trying to detect significant differences between the fish lengths at the different points.

\section{Degree of injury}

As the curimbatás try to ascend the Mogi-Guaçu river by the spillways or fish ladders, they can be wounded by shocking themselves



Fig. 2 - Draft of the Emas fall fish ladder. Encircled numbers indicate fish visual counting sites. 
against the dam wall. Therefore, the fish were inspected to detect the lesions in order to verify if an ontogenetic (fish size), temporal (different months) or spatial (different points) variation in the degree of injury existed.

The degrees of injury were classified as follows:

- 1: Fish in a normal state with no sign of impairment;

- 2: Fish with any kind of wounds; and

- 3: Extremely injured fish.

\section{Data analysis}

We used the Kruskal-Wallis non-parametric ANOVA and the corresponding a posteriori test for length measurements. For fish count data we used the RXC contingency table chi-square test (Vieira, 2003; Zar, 1996).

\section{RESULTS}

\section{Daily migration rhythm}

In Table 1 we observed the countings at points 1-4, of a total of 10,429 fish throughout the year (October/1992-September/1993. Note that point 1 and 2 were responsible for nearly $80 \%$ of the counted fish.

Fig. 3 shows the fish countings in the fish ladder from October (1992) to September (1993). Note that the bulk of migration seems to occur in September/October.

Pearson's correlation coefficient was determined between the data from the fish counts and the hourly air and water temperatures. These are both $\mathrm{r}^{2}=0.10^{* *}$ for $\mathrm{n}=768$. Although highly significant, these coefficients have little practical meaning.

TABLE 1

Number of fish counted during one day $(24 \mathrm{~h})$ per month for 5 min every hour at each of 4 points of Fig. 2 in the Emas fish ladder.

\begin{tabular}{|c|c|}
\hline Point number & Number of fish (\%) \\
\hline 1 & $4674(44.8)$ \\
\hline 2 & $3520(33.8)$ \\
\hline 3 & $2027(19.4)$ \\
\hline 4 & $208(2.0)$ \\
\hline Total & 10429 \\
\hline
\end{tabular}

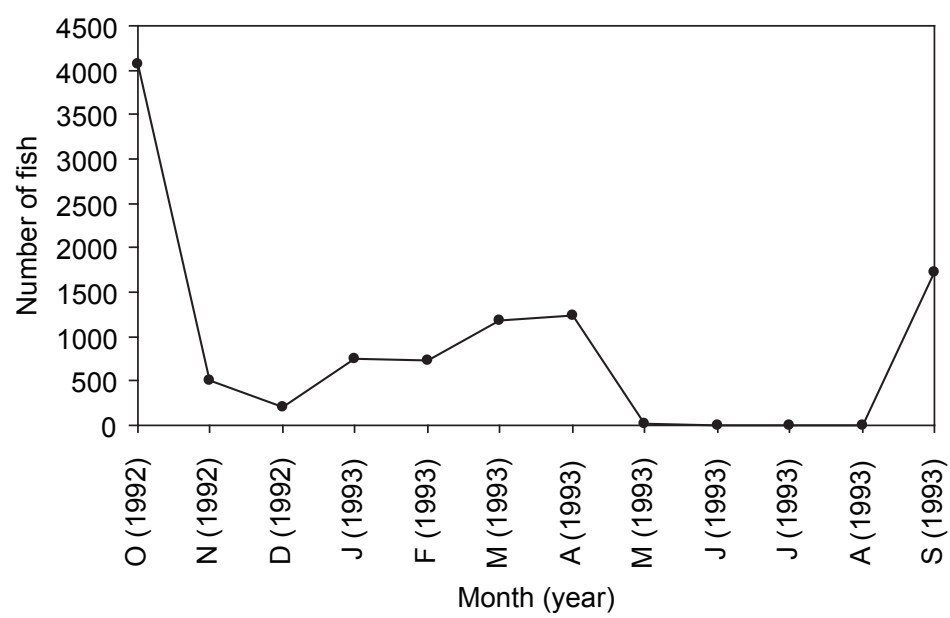

Fig. 3 - Number of fish counted during one day round ( $24 \mathrm{~h})$ per month, for 5 min every hour in the fish ladder at cachoeira de Emas, from October, 1992 to September, 1993. 


\section{Comparison of the length of the individuals per collection point}

We determined the mean lengths of the fish at the different points: $26.9 \mathrm{~cm}$ (ranging from $20.0-36.0 \mathrm{~cm})$ at point $5 ; 31.4 \mathrm{~cm}(22.0-60.5 \mathrm{~cm})$ at point $6 ; 40.4 \mathrm{~cm}(35.0-50.5 \mathrm{~cm})$ at point 7 ; and $31.8 \mathrm{~cm}(25.5-51.5 \mathrm{~cm})$ at point 8 .

In order to test the differences in the lengths at the different points, a non-parametric analysis of variance (Kruskal-Wallis test) that is little affected by the extreme observations was used. The test was significant at 5\%. Subsequently, we performed a two by two by multiple comparison a posteriori (Zar, 1996).The fish lengths were significantly different at $5 \%$ at points 5,$6 ; 5,7 ; 5,8 ; 6,7$. Only median lengths at points 6,8 were not significantly different. Just the larger fish (40.4 cm in average) tend to jump the ladder successfuly.

\section{Degree of injury}

The mean lengths of the fish observed for the degrees of injury were: $32.4 \mathrm{~cm}$ for degree 1; $29.1 \mathrm{~cm}$ for degree 2; and $27.9 \mathrm{~cm}$ for degree 3. Again we used the Kruskal-Wallis test which was significant at $5 \%$. A two by two multiple comparison a posteriori was also carried out (Zar,
1996). The following median lengths of degrees of injury are significant at 5\%: 1.2 and 1.3. We also test the hypothesis of possible learning by the fish in ascending the fish ladder by previous migrations. This being true, we would have found older fish (with a larger length) less wounded, which is actually the case.

In order to test the variation in the degrees of injury per collection point $(5,6,7$ and 8$)$ we used the Qui-squared test obtaining a significant value: 99.70** with 6 degrees of freedom (Table 2).

We also used the Qui-squared test to determine the temporal variation (different months) in relation to the degree of injury of the fish (Table 3), obtaining a significant value of $63.27 * *$ with 10 degrees of freedom.

\section{DISCUSSION}

\section{Daily migration rhythm}

The reproductive migration of the curimbatá in 1992-93, was most intense in October, representing $39.4 \%$ of the total of counted fish. However, Godoy (1959) observed more intense migratory rhythms for the species in December.

TABLE 2

Observed and expected frequencies (between brackets) by degree of injury at each sampling point $\left(X^{2}=99.70^{* *}, \mathrm{df}=6\right)$.

\begin{tabular}{|c|c|c|c|c|c|}
\hline \multicolumn{7}{|c|}{ Sampling point } \\
\hline Degree of injury & $\mathbf{5}$ & $\mathbf{6}$ & $\mathbf{7}$ & $\mathbf{8}$ & Total \\
\hline 1 & $58(76.7)$ & $54(46.8)$ & $44(21.5)$ & $0(11.0)$ & 156 \\
\hline 2 & $86(70.8)$ & $44(43.2)$ & $6(19.8)$ & $8(10.1)$ & 144 \\
\hline 3 & $38(34.4)$ & $13(21.0)$ & $1(9.6)$ & $18(4.9)$ & 70 \\
\hline Total & 182 & 111 & 51 & 26 & 370 \\
\hline
\end{tabular}

TABLE 3

Observed and expected frequencies (between brackets) by degree of injury at each month $\left(\mathrm{X}^{2}=63.27 * *, \mathrm{df}=10\right)$

\begin{tabular}{|l|c|c|r|r|}
\hline \multicolumn{5}{|c|}{ Degree of injury } \\
\hline Month (year) & $\mathbf{1}$ & $\mathbf{2}$ & $\mathbf{3}$ & Total \\
\hline October (1992) & $35(44.1)$ & $53(40.4)$ & $17(20.5)$ & 105 \\
\hline November (1992) & $23(35.2)$ & $37(32.4)$ & $24(16.4)$ & 84 \\
\hline December (1992) & $42(31.5)$ & $25(28.9)$ & $8(14.6)$ & 75 \\
\hline January (1993) & $41(23.5)$ & $10(21.6)$ & $5(10.9)$ & 56 \\
\hline February (1993) & $1(2.1)$ & $3(1.9)$ & $1(1.0)$ & 5 \\
\hline March (1993) & $17(22.7)$ & $18(20.8)$ & $19(10.5)$ & 54 \\
\hline Total & 159 & 146 & 74 & 379 \\
\hline
\end{tabular}


The yearly variable environmental factors, such as the water level mainly, also cause alterations in the migratory rhythm as they may or may not coincide with the months of previous years. In November and December there was a decrease in the number of counted fish, which gradually increased in the following months until May.

March and April together represent approximately $24 \%$ of the total, which is due to the late arrival of a shoal of Curimbatás, regionally called "temporão". By visual inspection, we noticed that the curimbatá from this shoal had a statistically inferior median length than the preceding months and a small amplitude of growth. By undertaking visual inspections of the genital papilla and dissecting a few individuals, we verified that these individuals were not in advanced gonadal stages. Therefore, the migration in this case does not occur due to reproductive stimuli as observed in preceding months, where it was visually possible to determine mature fish by a simple inspection of the cloacae.

Therefore, the aim of the upstream migration of the "temporão" shoal is not oviposition. What can the stimulus responsible for this migration be?

Bayley (1973) describes the migration of the sabalo in the Pilcomayo river as having first shoals (May and June) which contain larger individuals, whereas the July and August shoals are dominated by smaller fish. However, a relation can be found with the increase in the gonads from May to September that includes the whole period of upstream migration.

In May we observed some curimbatás, left over from the shoals that had appeared in the previous months (March and April) at the dam. In June, July and August no fish appeared at the site. This is because the observation site works as a route towards the reproduction areas and during this period the fish remain in areas where there is abundant food (feeding homes) to store fat reserves that will be metabolized during reproductive migration.

We verified that September was the beginning of the coming of the curimbatá shoals at Cachoeira de Emas due to the characteristics of the observation year. However, the reproductive migration occurs on a larger scale in October. The shoals continue to appear at the dam until April which therefore involves eight months of upstream migration, although probably during the last two months (March and April) the migration no longer has a reproductive aspect.

Approximately $79 \%$ of the total of curimbatás counted throughout the year occurred at points 1 and 2 (dam spillways). At these points the ascent of the river is practically impossible and few individuals are successful. Large shoals remain in front of these spillways, indicating that this point is unfortunately attractive for the fish that arrive at the dam.

The percentage of fish counted at the fish ladder was approximately $20 \%$. However a few implications can bring about difficulties concerning this quantification, since some fish ascend the fish ladder by the water brim making it impossible to count these individuals. The fish ladder at the Emas dam studied by Godoy (1987) seems to be very efficient for migratory fish, however various aspects must be taken into account in order for it to be attractive (Godoy, personal communication to MP Jr.). One of the main aspects is in relation to the volume of water that must be controlled according to the river's discharge. In the case of the fish ladder at the Cachoeira de Emas, the volume must be between 0.5-2.5 $\mathrm{m} \mathrm{sec}^{-1}$ (Godoy, 1987). Under $0.55 \mathrm{~m} \mathrm{sec}^{-1}$ it is not attractive for the passage of fish, and above $2.5 \mathrm{~m} \mathrm{sec}^{-1}$ the turbulence hinders the entrance of fish into the system (FAP 17, 1992).

Point 4 seems to be of little importance for the migration rhythm of the species. This is probably because it is a spillway where the volume of water is too large.

In relation to the curimbatás migratory rhythm, quantitative (fish number) and spatial (different points) variations occur during day and night periods. In October, we counted 2,504 fish in the diurnal period at points 1 and 2 , being considerably less in the nocturnal period (36) for the same points. Point 3 had smaller values (330) during the day compared to at night (858). Therefore we can consider the spillways as being more attractive for the fish during the day and the fish ladder at night. It was not possible to determine for sure what factor influences the spatial variation that occurs during the day and at night. The most apparent indication that may be determining this spatial variation is the fish ladder's illumination by a spotlight just above the ladder, in order to 
increase security for the night guard, where the fish are possibly attracted by the light and start to ascend the ladder at night. This aspect of the migration was verified mainly in October, where the number of fish observed was greater compared to the following months. The many histograms showing the nictemeral cycle of fish numbers is shown in Capeleti (1993).

\section{Comparison individual length per collection point}

From the results obtained with the KruskalWallis test and the comparisons a posteriori, we conclude that significant differences occur in relation to the median length of individuals at the different points.

An interesting fact is the differences in the median length of the fish at downstream (5, 6 and 8) and upstream (7) points of the dam. At first sight, it seemed as if only large curimbatás crossed the fish ladder since the mean length of the fish above the dam is $40.4 \mathrm{~cm}$. This hypothesis became suspicious after samples were taken downstream, in front of the ladder (point 8) where fish with smaller sizes $(\overline{\mathrm{x}}=31.8 \mathrm{~cm})$ were observed and also because we observed visually that fish of various sizes ascend the ladder. However, the presence of dourados, Salminus maxillosus, predators of the curimbatás, above the dam may prey intensely on the smaller curimbatás. Therefore, the fish that might be preyed on do not remain above the dam; only the larger curimbatás seem to remain at the site, since they are not molested by the dourados.

\section{Degree of injury}

The fact that the Kruskall-Wallis test is not significant when we leave out the fish from point 7 (which are larger and would jump the ladder at once) reinforces our finding that the smaller ones which keep trying to jump by the spillways hurt themselves. Therefore, an ontogenetic learning hypothesis cannot be examined with our data.

As it was detected by the Qui-squared test, a spatial (different points) variation occurs in the degree of injury of the fish. This variation was anticipated since many fish collided against the dam as they try to ascend the river. The shoals may remain in front of the spillways for a long time. It is possible that the shoals that arrive at the Emas dam are attracted in the first place due to the high water volume at the spillways. However, at some point some individuals leave this site and ascend the river by the fish ladder. The sampling undertaken at point 8 (in front of the fish ladder) shows that the fish are wounded possibly because they were previously trying to ascend the river by the spillways.

A significant difference was found between the degrees of injury in relation to the months of migration. This aspect is possibly influenced by the time at which the stationary shoals spend at the dam.

Acknowledgments - To UNESP and CNPq for partially supporting this research.

\section{REFERENCES}

AGOSTINHO, A. A., GOMES, L. C., SUZUKI, H. I. \& JÚLIO Jr., H. F., 2003, Migratory fish from the upper Parana river basin, Brazil. In: J. Carolsfeld, B. Harvey, C. Ross \& A. Baer (Eds.) Migratory fishes of South America: biology, fisheries and conservation status. World Fisheries Trust, British Columbia, Canada.

Agostinho, A. A., GOMES, L. C., FERnANDEZ, D. R. \& SUZUKI, H. I., 2002, Efficiency of fish ladders for Neotropical ichthyofauna. River Research and Applications, 18: 299-306.

BAYLEY, P. B., 1973, Studies on migratory characin, Prochilodus platensis Holmberg 1889 (Pisces, characoidei), in the River Pilcomayo, South America. Journal of Fish Biology, 5: 25-40.

BONDS, C. E., 1996, Biology of Fishes. Saunders, $2^{\text {nd }}$ ed., NY, 312 p.

BONETTO, A. A. \& PIGNALBERI, C., 1964, Nuevos aportes al concimento de las migraciones de los peces en los rios mesopotamicos de la republica Argentina. CONICIT Instituto Nacional de Limnologia, 1: 1-14.

BOnetTo, A. A., PIGNAlBeri, C., CORDiviola E. \& OLIVEIROS, Y., 1981, Informaciones complementares sobre migraciones de peces en la cuenca del plata. Physis, 30: 505-520.

CAPELETI, A. R., 1993, A migração e a dinâmica da população do curimbatá (Prochilodus lineatus) revisitado na Cachoeira de Emas do rio Mogi-Guaçu - S. P. Baccalaureate monography, UNESP, Rio Claro, SP, 57p.

FAP 17., 1992, Migration and Fish Pass Study. Fisheries Development Ltd. ODA., London, 67p.

GOdinho, H. P., GODINHO, A. L., FORMAGIO, P. S. \& TORQUATO, V. C., 1991, Fish ladder efficiency in a southeastern Brazilian river. Ciência e Cultura, 43(1): 63-67.

GODOY, M. P., 1954, Locais de desovas de peixes num trecho do rio Mogi-Guaçu, Estado de São Paulo, Brasil. Rev. Bras. Biol., 14: 375-396.

GODOY, M. P., 1957, Marcação de peixes no rio Mogi-Guaçu (Nota prévia). Rev. Bras. Biol., 17: 479-490. 
GODOY, M. P., 1959, Age, Growth, Sexual maturity, Behavior, Migration, Tagging and Transplantation of the curimbatá (Prochilodus scrofa Steindachner, 1881) of the MogiGuaçu river, São Paulo State, Brasil. An. Acad. Bras. Cienc., 31: 447-477.

GODOY, M. P., 1962, Marcação, migração e transplantação de peixes marcados na bacia do rio Paraná superior. Arquivos do Museu Nacional, 52: 105-113.

GODOY, M. P., 1967, Dez anos de observações sobre periodicidade migratória de peixes do rio Mogi-Guaçu. Rev. Bras. Biol., 27: 1-12.

GODOY, M. P., 1972, Brazilian Tagging experiments, fishes migration, and upper Paraná river basin ecosystem. Rev. Bras. Biol., 32: 473-484.

GODOY, M. P., 1987, A escada de peixes de Cachoeira de Emas, rio Mogi-Guaçu, Estado de São Paulo, Brasil. Com. Mus. Cienc. PUCRS, 43: 139-151.

LOWE-MCCONNELL, R., 1999, Estudos Ecológicos de Comunidades de Peixes Tropicais. Trad. A. E. M Vazzoler, A. A. Agostinho \& P. T. M. Cunningham, EDUSP, São Paulo, Brasil.
NORTHCOTE, T. G., 1984, Mechanisms of fish migration in fishes. In: J. D. Mcleave (ed.) NATO Conference Series on Marine Sciences, Washington D.C.

PAYNE, A. I., 1986, A Survey of the rio Pilcomayo sabalo fishery. Bol. Tec. - Department of Biological Sciences. Coventry Lancaster Polytechnic, Coventry, UK.

PETRERE, M., 1985, Migraciones de peces de agua dulce en America Latina: Algunos comentarios. FAO COPESCAL Doc Ocas., 1: 17p.

PETRERE, M., 1989, River fisheries in Brazil: A review. Regulated Rivers: Research \& Management, 4: 1-16.

QUIRÓS, R., 1988, Estruturas para assistir a los peces no salmoídeos en sus migraciones: America Latina FAO COPESCAL Doc TÉC., 5: 50p.

SVERLIJ, S. B., ROS, A. E. \& ORTI, G., 1993, Sinopsis de los datos biologicos y pesqueros del sabalo Prochilodus lineatus (Valenciennes, 1847). FAO Sinopsis sobre la Pesca, 154: 64.

VIEIRA, S., 2003, Bioestatística: tópicos avançados. Campus, Rio de Janeiro, 212p.

ZAR, J., 1996, Biostatistical Analysis. Prentice Hall, $2^{\text {nd }}$ ed., NJ, 662 p. 